\title{
Nematicidal activity of aqueous tinctures of plants against larvae of the nematode Strongyloides papillosus
}

\author{
Boyko, 0.0. ${ }^{1}$, Brygadyrenko, V.V. ${ }^{1,2^{*}}$
}

${ }^{1}$ Department of Parasitology, Veterinary and Sanitery Examination, Dnipro State Agrarian and Economic University, Sergiy Efremov St., 25, 49000, Dnipro, Ukraine

${ }^{2}$ Department of Zoology and Ecology, Oles Honchar Dnipro National University, Gagarin Av., 72, 49010, Dnipro, Ukraine

*Corresponding author: brigad@ua.fm

\section{ARTICLE HISTORY}

Received: 18 September 2020

Revised: 27 March 2021

Accepted: 28 March 2021

Published: 30 April 2021

\begin{abstract}
This research was undertaken to evaluate the nematicidal activity of various concentrations of aqueous tinctures of 80 plant species towards $L_{1-2}$ of $S$. papillosus. For the experiment with larvae of S. papillosus, there were used $0.19 \%, 0.75 \%$ and $3.00 \%$ aqueous tinctures of plants. Out of 80 tested species, nematicidal activity against $L_{1-2}$ of $S$. papillosus was displayed by 20 plants. The greatest activity $\left(\mathrm{LC}_{50}=0.060-0.069 \%\right)$ towards larvae of $S$. papillosus was exerted by Teucrium polium, Achillea millefolium, Genista tinctoria and UImus laevis. Less expressed nematicidal activity $\left(\mathrm{LC}_{50}=0.070-0.079 \%\right)$ was recorded for Thalictrum minus, Stachys recta, Falcaria vulgaris, Lavatera thuringiaca. Even lower effect $\left(\mathrm{LC}_{50}=0.080-0.089 \%\right)$ was shown by aqueous tinctures of Mentha $\times$ piperita, Achillea millefolium, Salvia nutans, Eryngium campestre and Cerasus fruticosa. The following plants could be arranged in declining order of effectiveness of nematicidal activity $\left(\mathrm{LC}_{50}=0.090-0.165 \%\right)$ Malus sylvestris, Tragopogon orientalis, Erigeron annuus, Grindelia squarrosa, Urtica dioica, Daucus carota, Medicago sativa, Carduus acanthoides, Ulmus minor and Hieracium umbellatum. A far weaker effect on the nematodes was displayed by Bromopsis inermis and Tragopogon podolicus. Aqueous tinctures of 60 other studied species of plants exhibited low nematicidal activity in $3.00 \%$ aqueous tincture, while in $0.19 \%$ and $0.75 \%$ aqueous tinctures, no nematicidal activity was seen. The results of the research suggest that in the conditions of natural ecosystems, some species of plants of the Apiaceae, Asteraceae, Fabaceae, Lamiaceae, Malvaceae, Rosaceae, Ulmaceae and Urticaceae families could reduce vitality of free-living $L_{1-2}$ larvae of $S$. papillosus.
\end{abstract}

Keywords: Strongylidae; Rhabditida; mortality; gastrointestinal helminthiases; anthelmintic preparations.

\section{INTRODUCTION}

Every year, farms experience large losses from outbreaks of helminthiases. Among ruminant nematodiases, gastrointestinal helminthiases are quite frequent (MatYusof et al., 2016; Rupa \& Portugaliza, 2016; Zvinorova et al., 2016; Chaudhary et al., 2017; de Almeida et al., 2018; Gupta et al., 2019; Lambacher et al., 2019; Puspitasari et al., 2019). Losses from these diseases may be inflicted not only by the death of animals, but also by decrease in the amount of dairy or meat products and reduction of their quality (Moreno \& Lanusse, 2017; Swai \& Wilson, 2017; Bellet et al., 2018; Fthenakis \& Papadopoulos, 2018; Rashid et al., 2018). Economic losses also occur due to the costs associated with use of synthetic anthelmintic preparations. At the same time, frequent application of such preparations may not provide the necessary positive effect due to the gradual development by the parasites of resistance to anthelmintic preparations
(Lyndal-Murphy et al., 2014; Dyary, 2015; Gárcia et al., 2016; Kotze \& Prichard, 2016; Singh et al., 2016; Ploeger \& Everts, 2018; Sangster et al., 2018; Baiak et al., 2019; Kelleher et al., 2020). Therefore, the search of alternative treatment of helmianthiases without synthetic anthelmintic preparations is a promising direction of studies on host animals and their parasites.

One of the directions of combating nematodoses is the use of medicinal plants (Ayaz et al., 2018; Oliveira Santos et al., 2019; Swargiary et al., 2020). They are used in both in vitro (De Paula Carlis et al., 2019; Esteban-Ballesteros et al., 2019; Maestrini et al., 2019; Piza et al., 2019; Boyko \& Brygadyrenko, 2018, 2019, 2020), and in vivo experiments (Sastya et al., 2018; Alowanou et al., 2019). Efficiency of plant extracts depends on the various conditions of the experiments. Most often alcoholic or hydro-alcoholic extracts are effective against nematodes (Eguale et al., 2007; Olmedo-Juárez et al., 2017; Tsehayneh \& Melaku, 2019). Quite often the published 
data reports the anthelmintic properties of aqueous plant tinctures (Khan et al., 2018; Nouri et al., 2019; Imani-Baran et al., 2020).

Nematodes of the genus Strongyloides Grassi, 1879 have several stages of development. Larvae of first-second stages (rhabditiformlarvae) live in the external environment. Their life cycle comprises two consecutive ways of development in the environment. In the first case second-stage larvae moult and transform into infective larvae (filariform). The second course of the development leads to formation of free-living females and males in the environment, which are able to produce a new generation. The type of development depends on many factors. The most important one is temperature. For example, infective larvae $\left(L_{3}\right)$ develop faster in lower temperatures, while free-living generations emerge in higher temperatures (Premvati, 1963; Nwaorgu, 1983; Shiwaku et al., 1988; Viney, 1996, 1999). Numerous experiments related to the struggle against infective larvae are performed all around the globe. However, the control of $\mathrm{L}_{1-2}$ in the environment is also important in order to combat strongyloidiasis.

Therefore, the objective of this study was to assess the in vitro effect of aqueous tinctures of plants collected in natural conditions in the south of Ukraine on $\mathrm{L}_{1-2}$ of Strongyloides papillosus (Wedl, 1856).

\section{MATERIAL AND METHODS}

\section{Collection and Identification of the Medicinal Plants}

Above-ground parts of medicinal plants were collected in the territory of Regional Landscape Park Samarsky Bor in Novomoskovsk district of Dnipropetrovsk Oblast (Ukraine). The zones of collection of plants were at the distance of over $3 \mathrm{~km}$ from industrial enterprises, ploughed fields and major highways. Samples from a total of 80 species of plants were identified and deposited in the Botanical Herbarium of Dnipro National University (Table 1).

\section{Preparation of the Tincture}

Tinctures were obtained during heating of $0.5 \mathrm{~g}$ of dry fragmented parts of plants (leaves, shoots, inflorescences, stigmas, bark - Table 1) in $150.55 \mathrm{~g}$ of distilled water $\left(90^{\circ} \mathrm{C}\right)$ over $15 \mathrm{~min}$ in the water bath. The obtained tincture was cooled at room temperature to $25^{\circ} \mathrm{C}$. Then the obtained tincture was percolated.

\section{Dilution of the Samples}

In the experiment three concentrations of aqueous tincture of each of the 80 species of plants were used: $3.00 \%, 0.75 \%$, and $0.19 \%$. Solution I was obtained by adding $150.55 \mathrm{~g}$ of distilled water to $5.0 \mathrm{~g}$ of dry fragmented parts of plants. To obtain solution II, $10 \mathrm{~g}$ of solution and $30.00 \mathrm{~g}$ of distilled water were used. Solution III was prepared by mixing $10 \mathrm{~g}$ of solution II and $29.47 \mathrm{~g}$ of distilled water.

\section{Larval Cultivation}

Feces were collected from naturally infected goats of the Clinical-Diagnostic Center of the Faculty of Veterinary Medicine of Dnipro State Agrarian-Economic University (Ukraine). Analysis of feces for presence of eggs of nematodes was performed using the McMaster technique. Nematode larvae were cultivated in feces for 3 days in the conditions of moistening in the temperature of $28^{\circ} \mathrm{C} . \mathrm{L}_{1-2}$ were extracted using the Baermann test (Zajac et al., 2011). Exposure for the exit of the larvae from the feces lasted for 2-4 $\mathrm{h}$.

\section{Larval Survival Test}

A total of $4 \mathrm{~mL}$ of water with larvae was poured in test tubes and centrifuged during 4 minutes at 1,500 rpm. Supernatant fluid $(3 \mathrm{~mL})$ was removed with a pipette. The sediment with larvae $(1 \mathrm{~mL})$ was uniformly mixed and $0.1 \mathrm{~mL}$ (60-110 larvae/ $0.1 \mathrm{~mL}$ ) was put into test tube $(1.5 \mathrm{~mL})$. Then, aqueous tinctures of plants were added - solutions I, II and III, $1.4 \mathrm{~mL}$ of each, to obtain respectively $3.00 \%, 0.75 \%$ and $0.19 \%$ of aqueous tinctures of plants in experimental test tubes. In each variant of the experiment, the surveys were performed in seven-fold replication $(n=7)$. Nematode larvae were kept in aqueous tinctures of plants and the control (distilled water) for $24 \mathrm{~h}$. Then, in the contents of each test tube, live and dead $L_{1-2}$ were counted under the microscope at 100x magnification.

\section{Statistical Analysis of the Data}

The statistical analysis of the results was performed through the set of Statistica 8.0 (StatSoft Inc., USA). For each set of 7 experiments, mean and standard deviations $(x \pm S D)$ were calculated for each set of 7 experiments. Reliability of differences of mortality of larvae in the control and aqueous tincture of plant was calculated using ANOVA. In Figure 1 and 2 , the small square in the centre corresponds to the median, the lower and upper edge of the large rectangle corresponds to first and third quartiles, respectively, the vertical segments, directed upward and downward from the rectangles, correspond to minimum and maximum values.

\section{RESULTS}

The experiment revealed that aqueous tinctures of 20 (3\%) of the tested plants exhibited notable nematicidal activity towards $L_{1-2}$ of $S$. papillosus (Table 1 ). Over $90 \%$ of mortality of first and second stage larvae of $S$. papillosus were observed during the influence of aqueous tinctures of E. campestre, $F$. vulgaris, A. millefolium, E. annuus, G. squarrosa, $T$. orientalis, $T$. podolicus, G. tinctoria, M. sativa, M. × piperita, S. nutans, S. recta, T. polium, L. thuringiaca, T. minus, C. fruticosa, M. sylvestris, $U$. laevis, U. minor, U. dioica. Less than $50 \%$ of mortality of first and second stage larvae of $S$. papillosus was found using aqueous tinctures of 26 species of plants.

Aqueous tinctures of plants of the Apiaceae family (Figure $1 \mathrm{a}-\mathrm{c}$ ) exhibited good results against rhabditiform larvae $\left(L_{1-2}\right)$ of $S$. papillosus. The most effective plants of this family were E. campestre and F. vulgaris. Exposure to plants of the Asteraceae family (Figure $1 \mathrm{~d}-\mathrm{j}$ ) killed over $80 \%$ of $\mathrm{L}_{1-2}$ larvae of $S$. papillosus using all the tested concentrations of aqueous tinctures of $A$. millefolium L., E. annuus and $T$. orientalis. Aqueous tinctures of low concentrations of the tested species of Fabaceae family in vitro displayed no expressed nematicidal properties against larvae of $S$. papillosus (Figure $1 \mathrm{k}, \mathrm{I})$.

Aqueous tinctures of four species of the Lamiaceae family (Figure $2 a-d$ ) $-M$. $\times$ piperita, S. nutans, S. recta and $T$. polium - caused death of $80 \%$ of nematode larvae in all three studied concentrations. Aqueous tincture of L. thuringiaca (Malvaceae) was also effective (Figure 2e) even in the lowest of the tested concentrations (0.19\%).

Tinctures of $B$. inermis (Poaceae) and $T$. minus (Ranunculaceae) (Figure 2f, g) in the concentration of $0.19 \%$ killed less than $80 \%$ of $S$. papillosus rhabditiform larvae. Plants of the Rosaceae (Figure $2 \mathrm{~h}-\mathrm{i}$ ) and Ulmaceae families (Figure $2 \mathrm{j}-\mathrm{l})$ had different efficiency against larvae: higher activity in all the studied concentrations was exhibited by $C$. fruticosa (Rosaceae), U. laevis (Ulmaceae). Aqueous tincture of $U$. dioica 
Table 1. Mortality (\%) of rhabditiform larvae $\left(\mathrm{L}_{1-2}\right)$ of $S$. papillosus exposed to aqueous tinctures of leaves from 80 species of plants during $24 \mathrm{~h}$ laboratory experiment $(x \pm S D, n=7)$

\begin{tabular}{|c|c|c|c|c|c|}
\hline Family & Species & Part of plant & $\begin{array}{c}\text { Mortality of } \\
\text { nematode larvae } \\
\text { in } 3.0 \% \text { plant } \\
\text { solution, } \%\end{array}$ & $\begin{array}{l}\text { Mortality of } \\
\text { nematode } \\
\text { larvae in } \\
\text { control, \% }\end{array}$ & $\begin{array}{l}\text { Reliability of } \\
\text { impact of } 3.0 \% \\
\text { plant solution } \\
\text { compared with } \\
\text { the control }\end{array}$ \\
\hline Amaryllidoideae & Narcissus poeticus L. & leaves & $20.3 \pm 7.5$ & $17.5 \pm 8.1$ & - \\
\hline Apiaceae & Daucus carota L. & leaves & $80.4 \pm 5.8$ & $19.0 \pm 6.5$ & $* * *$ \\
\hline Apiaceae & Eryngium campestre L. & leaves & $95.6 \pm 4.7$ & $15.7 \pm 4.0$ & $* * *$ \\
\hline Apiaceae & Falcaria vulgaris Bernh. & leaves & $95.2 \pm 6.4$ & $22.9 \pm 15.8$ & $* * *$ \\
\hline Apocynaceae & Asclepias syriaca $\mathrm{L}$. & leaves & $34.3 \pm 7.4$ & $22.5 \pm 6.5$ & - \\
\hline Aristolochiaceae & Aristolochia clematitis L. & leaves & $57.4 \pm 10.6$ & $17.5 \pm 8.1$ & ** \\
\hline Asparagaceae & Asparagus officinalis $\mathrm{L}$. & shoots & $49.0 \pm 6.2$ & $17.5 \pm 8.1$ & $*$ \\
\hline Asteraceae & Achillea millefolium $\mathrm{L}$. & inflorescences & $99.2 \pm 1.1$ & $15.4 \pm 4.4$ & $* * *$ \\
\hline Asteraceae & Anthemis subtinctoria Dobrocz. & inflorescences & $41.7 \pm 7.4$ & $19.6 \pm 8.8$ & $*$ \\
\hline Asteraceae & Artemisia vulgaris $\mathrm{L}$. & shoots & $62.5 \pm 11.2$ & $22.5 \pm 8.6$ & ** \\
\hline Asteraceae & Calendula officinalis L. & inflorescences & $54.7 \pm 7.4$ & $19.6 \pm 8.8$ & $* *$ \\
\hline Asteraceae & Carduus acanthoides L. & leaves & $88.4 \pm 7.9$ & $27.8 \pm 19.1$ & $* * *$ \\
\hline Asteraceae & Centaurea scabiosa L. & leaves & $50.7 \pm 9.1$ & $22.5 \pm 6.5$ & * \\
\hline Asteraceae & Cichorium intybus L. & shoots & $47.8 \pm 9.3$ & $22.1 \pm 10.4$ & * \\
\hline Asteraceae & Cyclachaena xanthiifolia (Nutt.) Fresen. & leaves & $20.7 \pm 7.0$ & $11.8 \pm 6.2$ & - \\
\hline Asteraceae & Erigeron annuus (L.) Desf. & shoots & $95.8 \pm 5.9$ & $11.0 \pm 7.4$ & $* * *$ \\
\hline Asteraceae & Galatella villosa (L.) Rchb. f. & shoots & $65.2 \pm 8.9$ & $14.3 \pm 6.7$ & $* *$ \\
\hline Asteraceae & Grindelia squarrosa (Pursh.) Dunal & shoots & $100.0 \pm 0.0$ & $33.0 \pm 6.0$ & $* * *$ \\
\hline Asteraceae & Hieracium umbellatum $\mathrm{L}$. & shoots & $67.3 \pm 8.5$ & $33.0 \pm 8.5$ & $* * *$ \\
\hline Asteraceae & Lactuca serriola $\mathrm{L}$. & shoots & $59.8 \pm 10.4$ & $22.5 \pm 8.6$ & $* *$ \\
\hline Asteraceae & Tragopogon orientalis L. & leaves & $97.5 \pm 1.6$ & $20.4 \pm 8.1$ & $* * *$ \\
\hline Asteraceae & T. podolicus (DC.) S. A. Nikitin & leaves & $94.2 \pm 7.1$ & $20.4 \pm 8.1$ & $* * *$ \\
\hline Boraginaceae & Echium vulgare $\mathrm{L}$. & shoots & $26.1 \pm 8.1$ & $11.8 \pm 6.2$ & - \\
\hline Boraginaceae & Nonea pulla (L.) DC. & shoots & $50.3 \pm 9.0$ & $22.1 \pm 10.4$ & * \\
\hline Brassicaceae & Descurainia sophia (L.) Webb ex Prantl & shoots & $44.3 \pm 8.4$ & $17.5 \pm 8.1$ & * \\
\hline Campanulaceae & Campanula sibirica $\mathrm{L}$. & shoots & $62.8 \pm 8.7$ & $17.5 \pm 8.1$ & $* *$ \\
\hline Caryophyllaceae & Gypsophila paniculata L. & shoots & $55.9 \pm 9.1$ & $14.3 \pm 6.7$ & $* *$ \\
\hline Caryophyllaceae & Silene dichotoma Ehrh. & shoots & $66.7 \pm 10.9$ & $22.5 \pm 8.6$ & $* *$ \\
\hline Caryophyllaceae & S. sibirica (L.) Pers. & shoots & $67.4 \pm 11.4$ & $22.1 \pm 10.4$ & ** \\
\hline Convolvulaceae & Convolvulus arvensis $\mathrm{L}$. & shoots & $57.4 \pm 8.0$ & $11.8 \pm 6.2$ & * \\
\hline Cornaceae & Cornus sanguinea $\mathrm{L}$. & leaves & $22.6 \pm 7.6$ & $17.5 \pm 8.1$ & - \\
\hline Dipsacaceae & Knautia arvensis (L.) J. M. Coult. & shoots & $27.9 \pm 6.2$ & $22.1 \pm 10.4$ & - \\
\hline Ericaceae & Vaccinium vitis-idaea $\mathrm{L}$. & shoots & $48.5 \pm 7.3$ & $17.5 \pm 8.1$ & $*$ \\
\hline Euphorbiaceae & Euphorbia stepposa Zoz ex Prokh. & shoots & $46.3 \pm 9.2$ & $14.3 \pm 6.7$ & * \\
\hline Fabaceae & Astragalus cicer $\mathrm{L}$. & shoots & $70.7 \pm 10.7$ & $22.5 \pm 6.5$ & $* *$ \\
\hline Fabaceae & Chamaecytisus austriacus (L.) Link & shoots & $68.5 \pm 8.7$ & $19.6 \pm 8.8$ & $* *$ \\
\hline Fabaceae & Genista tinctoria L. & shoots & $98.5 \pm 1.0$ & $33.0 \pm 6.0$ & $* * *$ \\
\hline Fabaceae & Lathyrus tuberosus L. & shoots & $49.2 \pm 8.1$ & $14.3 \pm 6.7$ & * \\
\hline Fabaceae & Medicago falcata $\mathrm{L}$. & shoots & $74.0 \pm 12.4$ & $14.3 \pm 6.7$ & ** \\
\hline Fabaceae & M. Iupulina L. & shoots & $31.9 \pm 6.0$ & $11.8 \pm 6.2$ & - \\
\hline Fabaceae & M. sativa $\mathrm{L}$. & shoots & $94.0 \pm 5.5$ & $19.0 \pm 6.5$ & $* * *$ \\
\hline Fabaceae & Melilotus albus Medik. & shoots & $57.4 \pm 6.9$ & $22.5 \pm 6.5$ & $* *$ \\
\hline Fagaceae & Quercus robur L. & leaves & $21.9 \pm 7.0$ & $11.8 \pm 6.2$ & - \\
\hline Fagaceae & Q. robur $\mathrm{L}$. & bark & $17.5 \pm 9.3$ & $14.3 \pm 6.7$ & - \\
\hline Hypericaceae & Hypericum perforatum L. & shoots & $62.7 \pm 10.7$ & $22.1 \pm 10.4$ & $* *$ \\
\hline Lamiaceae & Ballota nigra $\mathrm{L}$. & shoots & $31.9 \pm 6.5$ & $14.3 \pm 6.7$ & - \\
\hline Lamiaceae & Mentha $\times$ piperita $\mathrm{L}$. & shoots & $98.6 \pm 2.9$ & $19.0 \pm 6.5$ & $* * *$ \\
\hline Lamiaceae & Phlomis pungens Willd. & shoots & $71.3 \pm 4.8$ & $22.5 \pm 8.6$ & $* * *$ \\
\hline Lamiaceae & Salvia nutans $\mathrm{L}$. & shoots & $96.3 \pm 3.1$ & $27.8 \pm 19.1$ & $* * *$ \\
\hline Lamiaceae & S. tesquicola Klokov \& Pobed. & shoots & $59.4 \pm 10.6$ & $14.3 \pm 6.7$ & $* *$ \\
\hline Lamiaceae & Stachys recta $\mathrm{L}$. & shoots & $96.7 \pm 3.8$ & $27.8 \pm 19.1$ & $* * *$ \\
\hline Lamiaceae & Teucrium polium L. & shoots & $96.4 \pm 2.7$ & $33.0 \pm 6.0$ & $* * *$ \\
\hline Lamiaceae & Thymus marschallianus Willd. & shoots & $14.3 \pm 4.9$ & $12.0 \pm 6.2$ & - \\
\hline Linaceae & Linum hirsutum L. & shoots & $60.7 \pm 9.2$ & $11.8 \pm 6.2$ & ** \\
\hline Malvaceae & Lavatera thuringiaca $\mathrm{L}$. & leaves & $97.4 \pm 3.2$ & $15.7 \pm 4.0$ & $* * *$ \\
\hline Oleaceae & Syringia vulgaris $\mathrm{L}$. & leaves & $39.0 \pm 6.3$ & $17.5 \pm 8.1$ & $*$ \\
\hline Onagraceae & Chamaenerion angustifolium (L.) Scop. & leaves & $20.3 \pm 6.2$ & $19.6 \pm 8.8$ & - \\
\hline Onagraceae & Epilobium palustre L. & shoots & $22.4 \pm 6.6$ & $17.5 \pm 8.1$ & - \\
\hline Poaceae & Aegilops cylindrica Host & shoots & $56.2 \pm 6.8$ & $22.5 \pm 6.5$ & $* *$ \\
\hline Poaceae & Bromopsis inermis (Leyss.) Holub & shoots & $86.4 \pm 8.7$ & $20.4 \pm 8.1$ & $* * *$ \\
\hline Poaceae & Bromus squarrosus L. & shoots & $50.0 \pm 11.3$ & $22.5 \pm 8.6$ & $*$ \\
\hline Poaceae & Calamagrostis epigejos (L.) Roth & shoots & $53.2 \pm 7.6$ & $22.5 \pm 8.6$ & * \\
\hline Poaceae & Triticum aestivum $\mathrm{L}$. & shoots & $51.1 \pm 9.4$ & $19.6 \pm 8.8$ & $*$ \\
\hline Poaceae & Zea mays $\mathrm{L}$. & stamen filaments & $52.4 \pm 7.4$ & $19.6 \pm 8.8$ & $* *$ \\
\hline Polygonaceae & Polygonum aviculare L. & shoots & $60.0 . \pm 8.6$ & $14.3 \pm 6.7$ & ** \\
\hline
\end{tabular}




\begin{tabular}{|c|c|c|c|c|c|}
\hline Family & Species & Part of plant & $\begin{array}{c}\text { Mortality of } \\
\text { nematode larvae } \\
\text { in } 3.0 \% \text { plant } \\
\text { solution, } \%\end{array}$ & $\begin{array}{l}\text { Mortality of } \\
\text { nematode } \\
\text { larvae in } \\
\text { control, \% }\end{array}$ & $\begin{array}{l}\text { Reliability of } \\
\text { impact of } 3.0 \% \\
\text { plant solution } \\
\text { compared with } \\
\text { the control }\end{array}$ \\
\hline Ranunculaceae & Nigella arvensis L. & shoots & $51.2 \pm 7.8$ & $11.8 \pm 6.2$ & $* *$ \\
\hline Ranunculaceae & Thalictrum minus L. & leaves & $97.8 \pm 2.8$ & $28.7 \pm 4.8$ & $* * *$ \\
\hline Resedaceae & Reseda lutea $\mathrm{L}$. & shoots & $52.2 \pm 5.8$ & $19.6 \pm 8.8$ & $*$ \\
\hline Rosaceae & Agrimonia eupatoria L. & leaves & $44.5 \pm 10.4$ & $22.1 \pm 10.4$ & - \\
\hline Rosaceae & Cerasus fruticosa Pall. & leaves & $96.7 \pm 2.2$ & $21.7 \pm 5.3$ & $* * *$ \\
\hline Rosaceae & Fragaria vesca $\mathrm{L}$. & leaves & $45.1 \pm 12.4$ & $19.6 \pm 8.8$ & $*$ \\
\hline Rosaceae & Malus sylvestris Mill. & leaves & $97.4 \pm 1.2$ & $33.0 \pm 8.5$ & $* * *$ \\
\hline Rosaceae & Potentilla argentea $\mathrm{L}$. & shoots & $22.5 \pm 8.0$ & $17.5 \pm 8.1$ & - \\
\hline Rosaceae & Rubus caesius L. & shoots & $16.7 \pm 4.9$ & $14.3 \pm 6.7$ & - \\
\hline Sapindaceae & Acer tataricum L. & shoots & $26.2 \pm 5.0$ & $22.5 \pm 8.6$ & - \\
\hline Solanaceae & Licium barbarum L. & shoots & $80.8 \pm 5.3$ & $14.3 \pm 6.7$ & $* * *$ \\
\hline Typhaceae & Typha latifolia L. & leaves & $48.8 \pm 11.2$ & $22.5 \pm 8.6$ & $*$ \\
\hline Ulmaceae & Ulmus laevis Pall. & shoots & $92.5 \pm 4.5$ & $28.7 \pm 4.8$ & $* * *$ \\
\hline Ulmaceae & U. minor Mill. & shoots & $98.8 \pm 2.0$ & $21.7 \pm 5.3$ & $* * *$ \\
\hline Urticaceae & Urtica dioica $\mathrm{L}$. & shoots & $91.7 \pm 5.3$ & $19.0 \pm 6.5$ & $* * *$ \\
\hline Violaceae & Viola ambigua Waldst. \& Kit. & leaves & $35.2 \pm 7.2$ & $22.1 \pm 10.4$ & - \\
\hline
\end{tabular}

Reliability of differences in mortality of larvae in the control and plant solution was calculated using ANOVA: $*-P<0.05, * *-P<0.01, * * *-P<0.001$.
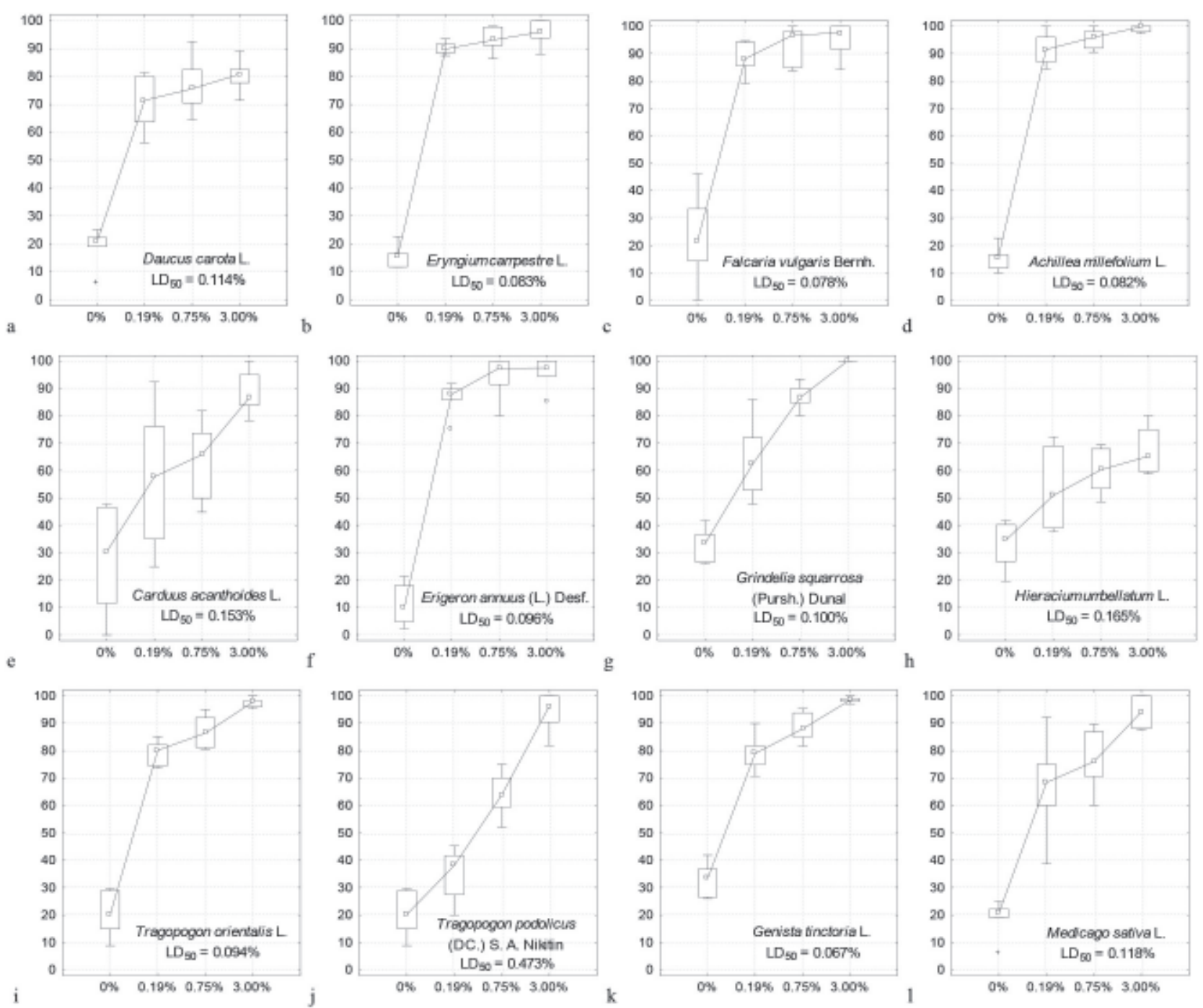

Figure 1. Influence of aqueous tinctures of Apiaceae $(a-c)$, Asteraceae $(d-j)$ and Fabaceae $(k, I)$ on mortality of rhabditiform larvae $\left(L_{1-2}\right)$ of $S$. papillosus during $24 \mathrm{~h}$ experiment $(n=7)$. 

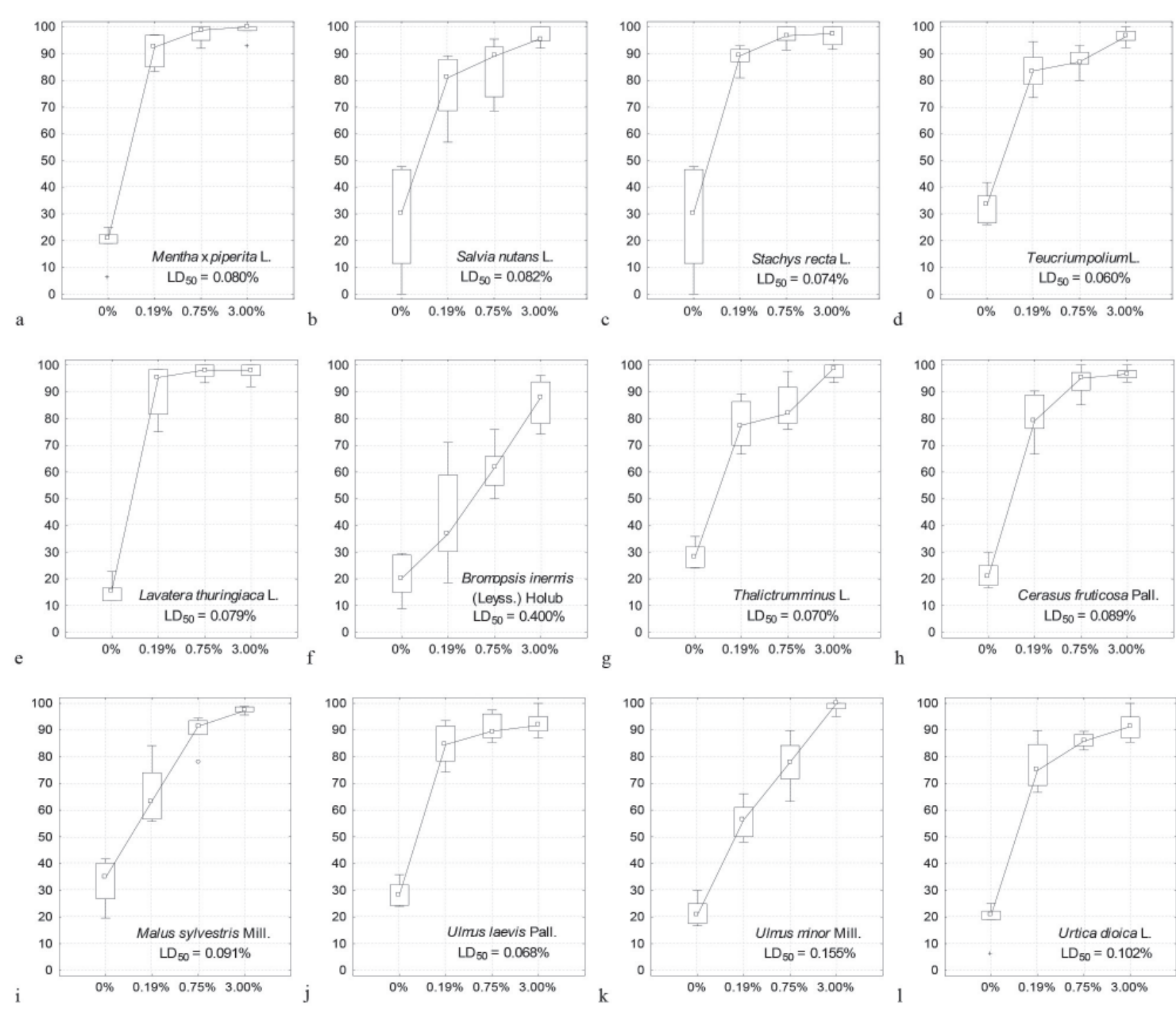

Figure 2. Influence of aqueous tinctures of plants of families Lamiaceae (a-d), Malvaceae (e), Poaceae (f), Ranunculaceae (g), Rosaceae $(\mathrm{h}, \mathrm{i})$, Ulmaceae $(\mathrm{j}, \mathrm{k})$ and Urticaceae (I) on mortality of rhabditiform larvae $\left(\mathrm{L}_{1-2}\right)$ of $S$. papillosus during $24 \mathrm{~h}$ experiment $(n=7)$.

(Urticaceae) in the concentration of $0.19 \%$ affected less than $80 \%$ of the studied stages of larvae of S. papillosus (Figure 21 ).

Highest parameters of $\mathrm{LC}_{50}(0.060-0.069 \%)$ regarding $\mathrm{L}_{1-2}$ S. papillosus belonged to T. polium, A. millefolium, G. tinctoria and $U$. laevis. Lower parameters $\left(L_{50}=0.070-0.079 \%\right)$ were recorded for $T$. minus, $S$. recta, $F$. vulgaris, L. thuringiaca. This parameter was no lower than $0.08 \%$ for $M . \times$ piperita, $A$. millefolium, S. nutans, E. campestre and C. fruticosa. Aqueous tinctures of $M$. sylvestris, $T$. orientalis, $E$. annuus, $G$. squarrosa, $U$. dioica, D. carota, M. sativa, C. acanthoides, U. minor and $H$. umbellatum exhibited less notable nematicidal properties against $\mathrm{L}_{1-2} \mathrm{~S}$. papillosus $\left(\mathrm{LC}_{50}=0.090-0.165 \%\right)$. Parameter $\mathrm{LC}_{50}$ for $B$. inermis and $T$. podolicus was even lower $-0.40 \%$ and $0.47 \%$, respectively (Figure 1,2 ).

\section{DISCUSSION}

In the present study, the plants from the Samarsky Bor Regional Landscape Park (Ukraine) were studied for nematicidal properties against $\mathrm{L}_{1-2}$ of $S$. papillosus in in vitro experiments. The in vitro evaluation showed that 20 species of plants cause death to $\mathrm{L}_{1-2}$ S. papillosus. Among them, 13 species (E. campestre, F. vulgaris, A. millefolium, E. annuus, $T$. orientalis, G. tinctoria, M. × piperita, S. nutans, S. recta, T. polium, $L$. thuringiaca, $C$. fruticosa, $U$. laevis) were effective against $L_{1-2}$ even in the lowest concentration of aqueous tinctures (0.19\%).

Surveys on anthelmintic properties of plants against species of the Strongyloides genus have also been conducted by other authors. Anthelmintic activity of Piper retrofractum Vahl has been studied in in vitro conditions against $L_{3}$ of $S$. stercoralis (Bavay, 1876) (Sangkhantree et al., 2018; Riyong et al., 2020). Boonmars et al. (2005) reported antiparasitic activity of Cardiospermum halicacabum L., and El-Sherbini \& Osman (2013) - Mangifera indica L. against larvae of the same stage of the development. Ismail et al. (2016) determined anthelmintic properties of Lawsonia inermis L. against larvae of Strongyloides spp. Moraes et al. (2017) and Cabral et al. (2019) studied the impact of some constituents of Carica papaya L. on eggs and larvae of Strongyloides venezuelensis (Brumpt, 1934). Extract of Siparuna guianensis Aublet also exhibited high anthelmintic activity (Carvalho et al., 2019) 
towards eggs and larvae of S. venezuelensis Brumpt, 1934. Ethanol extract from Spondias mombin L. and its aqueous fraction (Bastos et al., 2017) also demonstrated $100 \%$ in vitro efficiency against parasitic females of $S$. venezuelensis. Similar experiments (Rehder et al., 2014) were also performed using Labramia bojeri A. DC.

The impact of other plants on the nematode S. papillosus has been reported earlier (Boyko \& Brygadyrenko, 2016, 2019; Boyko et al., 2020). Among the species of plants studied earlier, significant impact on $\mathrm{L}_{1-2} S$. papillosus was exerted by Salvia sclarea L., Matricaria chamomilla L., Petroselinum crispum (Mill.), Taraxacum officinale F. H. Wigg., Sanguisorba officinalis L., Ambrosia artemisiifolia L., Arctiumminus (Hill) Bernh., Lotus ucrainicus Klok., Juniperus communis L., J. sabina L., Thuja occidentalis L., Aristolochia manshuriensis Kom., Celastrus scandens L., Colchicum autumnale L., Laburnum anagyroides Medik., Wisteria sinensis (Sims) DC., Quercus petraea subsp. iberica (Steven ex M. Bieb.) Krassiln., Ginkgo biloba L., Magnolia kobus DC., Ailanthus altissima (Mill.) Swingle.

In this study, the shoots of $S$. nutans had influence similar to inflorescences of $S$. sclarea. Exposure to aqueous tinctures led to death of more than $80 \%$ of $\mathrm{L}_{1-2} \mathrm{~S}$. papillosus in all the tested concentrations $(3.00 \%, 0.75 \%$, and $0.19 \%)$. Differences between the results were seen for the effect of $S$. tesquicola. Aqueous tincture of its shoots in $3 \%$ concentration caused death to about $60 \%$ of larvae. Significant differences were also seen for plants of Quercus genus. Tinctures of $Q$. robur had no effect on vitality of larvae, unlike $Q$. petraea subsp. iberica, in $3 \%$ aqueous tincture of which the vitality of larvae did not exceed $6 \%$. Interesting results were observed for the use of $M$. falcata, M. lupulina, and $M$. sativa. The strongest effect on $L_{1-2} S$. papillosus was shown by aqueous tincture of above-ground part of plants of $M$. sativa. Such differences perhaps may be related to species peculiarities of chemical composition of plants of the Medicago genus.

Experiments in in vitro conditions regarding the effect of alcohol extract of $M$. piperita on the development of eggs and nematode larvae (Haemonchus contortus (Rudolphi, 1803) were performed by Carvalho et al. (2012): LC 50 of mint extracts accounted for $37 \mathrm{mg} / \mathrm{L}$ regarding the development of eggs, and $18 \mathrm{mg} / \mathrm{L}$ regarding larvae. In our surveys, the value of $\mathrm{LC}_{50}$ for $M$. piperita was $80 \mathrm{mg} / \mathrm{L}$, indicating higher efficiency of alcohol extract compared with aqueous tincture.

The conditions of maintenance and feeding of agricultural animals are among the main factors of their productivity (Zazharska et al., 2018). Currently, many studies focus on the intensity of helminthic diseases in the conditions of pasture grazing of animals. Some pasture plants have anthelmintic properties. Marley et al. (2005) demonstrated that lambs grazing on lucerne had fewer adult nematodes of Teladorsagia circumcincta (Stadelman, 1894) than lambs grazing on ryegrass or red clover. Our in vitro results also indicate the anthelmintic properties of $M$. sativa. Over $90 \%$ of larvae died in $3 \%$ aqueous solution. Niezen et al. (2002) demonstrated that in feces of lambs which grazed $M$. sativa in the pasture in summer and autumn, the amount of eggs of Trichostrongylus colubriformis was insignificantly reduced compared to the control. Athanasiadou and Houdijk (2010) describe an experiment with grazing animals on bioactive forages. The best results were obtained with $C$. intybus. The studies regarding the in vitro effect of aqueous tincture of $C$. intybus on $\mathrm{L}_{1-2}$ of $S$. papillosus revealed no nematicidal properties in this plant. Over $50 \%$ of larvae remained vital during $24 \mathrm{~h}$ in different concentrations. Perhaps, the difference of our results is associated with performing the experiment in vitro, and not in vivo.

\section{CONCLUSION}

Study of anthelmintic properties of pasture plants are of great importance as an alternative treatment of helminthiases of animals. Out of 80 species of plants used in the study, only 20 species of plants exerted nematicidal activity towards $L_{1-2} S$. papillosus. Among them, 13 species (E. campestre, F. vulgaris, A. millefolium, E. annuus, T. orientalis, G. tinctoria, M. × piperita, S. nutans, S. recta, T. polium, L. thuringiaca, $C$. fruticosa, $U$. laevis) effectively affected $L_{1-2}$ even in lowest $(0.19 \%)$ concentration of the tested aqueous tinctures. Lowest parameters of $\mathrm{LC}_{50}(0.060-0.069 \%)$ regarding larvae of S. papillosus were recorded for T. polium, A. millefolium, $G$. tinctoria and $U$. laevis. These results would be interesting for future in vivo experiments in pasture conditions so as to decrease the use of synthetic anthelmintic preparations.

\section{ACKNOWLEDGEMENT}

This work was supported by the Ministry of Education and Science of Ukraine (grant 0120U102384).

\section{Competing Financial Interests}

The authors declare no competing interests.

Conflict of Interest

The authors declares that they have no conflict of interests.

\section{REFERENCES}

Alowanou, G.G., Azando, E.V.B., Adenilé, A.D., Koudandé, D.O., Chrysostome, C.A.M. \& Hounzangbé-Adoté, S.M. (2019). Evaluation of the in vivo anthelmintic properties of Mitragyna inermis (Willd.) as a livestock dewormer against parasitic hematophagous worm Haemonchus contortus infections in different breeds of lambs. Tropical Animal Health and Production 52: 309-319. https://doi.org/10.1007/ s11250-019-02014-w

Atanásio-Nhacumbe, A., Ayres, M.C.C., Lambert, S.M. \& Souza, B.P. (2017). Anthelmintic resistance in gastrointestinal nematodes of goats in Southern Mozambique. Veterinary Medicine and Animal Health 9: 313-319. https://dx.doi.org/ 10.5897/JVMAH2017.0597

Athanasiadou, S. \& Houdijk, J.G.M. (2010). Nutrition and immunity in animal disease: Lessons from parasitic gastroenteritis. In: Dietary Components and Immune Function, Watson, R.R., Zibadi, S. \& Preedy, V.R. (editors). Totowa: Humana Press, pp. 63-74. https://doi.org/10.1007/ 978-1-60761-061-8_4

Athanasiadou, S., Tzamaloukas, O., Kyriazakis, I., Jackson, F. \& Coop, R.L. (2005). Testing for direct anthelmintic effects of bioactive forages against Trichostrongylus colubriformis in grazing sheep. Veterinary Parasitology 127: 233-243. https://doi.org/10.1016/j.vetpar.2004.09.031

Ayaz, M.M., Nazir, M.M., Samad, N., Zubair, M., Hanif, M., Aziz, M., Sheikh, A.S., Akbar, A., Waheed, A. \& Zaman, A. (2018). Parasitism in goats: Husbandry management, range management, gut immunity and therapeutics. In: Goat Science, Kukovics, S. (editor). London: IntechOpen, pp. 756805. https://doi.org/10.5772/intechopen.74203

Baiak, B.H.B., Lehnen, C.R. \& da Rocha, R.A. (2019). Anthelmintic resistance of injectable macrocyclic lactones in cattle: A systematic review and meta-analysis. Revista Brasileira de Parasitologia Veterinária 28: 59-67. https://doi.org/ 10.1590/s1984-296120180093 
Bastos, L.A.D., Ueta, M.T., Garcia, V.L., de Oliveira, R.N., Pinto, M.C., Mendes, T.M.F. \& Allegretti, S.M. (2017). Ethanolic extracts of different fruit trees and their activity against Strongyloides venezuelensis. International Journal of Modern Biological Research 5: 1-7.

Bellet, C., Green, M.J., Bradley, A.J. \& Kaler, J. (2018). A longitudinal study of gastrointestinal parasites in English dairy farms. Practices and factors associated with first lactation heifer exposure to Ostertagia ostertagi on pasture. Journal of Dairy Science 101: 537-546. https://doi.org/ 10.3168/jds.2017-12952

Boonmars, T., Khunkitti, W., Sithithaworn, P. \& Fujimaki, Y. (2005). In vitro antiparasitic activity of extracts of Cardiospermum halicacabum against third-stage larvae of Strongyloides stercoralis. Parasitology Research 97: 417-419. https://doi.org/10.1007/s00436-005-1470-z

Boyko, O.O. \& Brygadyrenko, V.V. (2016). Influence of water infusion of medicinal plants on larvae of Strongyloides papillosus (Nematoda, Strongyloididae). Visnyk of Dnipropetrovsk University, Biology, Ecology 24: 519-525. https://doi.org/10.15421/011670

Boyko, O.O. \& Brygadyrenko, V.V. (2018). The impact of certain flavourings and preservatives on the survivability of larvae of nematodes of Ruminantia. Regulatory Mechanisms in Biosystems 9: 118-123. https://doi.org/10.15421/021817

Boyko, O.O. \& Brygadyrenko, V.V. (2019). Nematocidial activity of aqueous solutions of plants of the families Cupressaceae, Rosaceae, Asteraceae, Fabaceae, Cannabaceae and Apiaceae. Biosystems Diversity 27: 227-232. https://doi.org/ 10.15421/011931

Boyko, O.O., Kabar, A.M. \& Brygadyrenko, V.V. (2020). Nematicidal activity of aqueous tinctures of medicinal plants against larvae of the nematodes Strongyloides papillosus and Haemonchus contortus. Biosystems Diversity 28: 119-123. https://doi.org/10.15421/012016

Cabral, E.R.M., Moraes, D., Levenhagen, M.A., de Matos, R.A.F., Costa-Cruz, J.M. \& Rodrigues, R.M. (2019). In vitro ovicidal and larvicidal activity of Carica papaya seed hexane extract against Strongyloides venezuelensis. Revista do Instituto de Medicina Tropical de São Paulo 61: e59. https://doi.org/ 10.1590/s1678-9946201961059

Carvalho, C.O., Chagas, A.C.S., Cotinguiba, F., Furlan, M., Brito, L.G., Chaves, F.C.M., Stephan, M.P., Bozzo, H.R. \& Amarante, A.F.T. (2012). The anthelmintic effect of plant extracts on Haemonchus contortus and Strongyloides venezuelensis. Veterinary Parasitology 183: 260-268. https://doi.org/10.1016/ j.vetpar.2011.07.051

Carvalho, V.F., Ramos, L. dos A., da Silva, C.A., Nebo, L., Moraes, D., da Silva, F.F.A., da Silva, N.C.A., Rodrigues Junior, R. de O., de Souza, R.M. \& Rodrigues, R.M. (2019). In vitro anthelmintic activity of Siparuna guianensis extract and essential oil against Strongyloides venezuelensis. Journal of Helminthology 94: e50. https://doi.org/10.1017/s0022149 x19000282

Chaudhary, R.B. \& Maharjan, M. (2017). Parasitic infection in blackbuck (Antilope cervicapra Linnaeus, 1758) of Blackbuck Conservation Area, Bardiya and Shuklaphanta Wildlife Reserve, Kanchanpur, Western Nepal. Nepal Journal of Environmental Science 5: 9-17. https://doi.org/10.3126/ njes.v5i0.22710

De Almeida, F.A., Bassetto, C.C., Amarante, M.R.V., de Albuquerque, A.C.A., Starling, R.Z.C. \& do Amarante, A.F.T. (2018). Helminth infections and hybridization between Haemonchus contortus and Haemonchus placei in sheep from Santana do Livramento, Brazil. Revista Brasileira de Parasitologia Veterinária 27: 280-288. https://doi.org/10.1590/ s1984-296120180044
De Paula Carlis, M.S., Féboli, A., de Laurentiz, A.C., da Silva Filardi, R., de Oliveira, A.H.P., Andrade e Silva, M.L., dos Anjos, L.A., Magalhaes, L.G. \& da Silva de Laurentiz, R. (2019). In vitro anthelmintic activity of the crude hydroalcoholic extract of Piper cubeba fruits and isolated natural products against gastrointestinal nematodes in sheep. Veterinary Parasitology 275: 108932. https://doi.org/10.1016/ j.vetpar.2019.108932

Dyary, H.O. (2015). Veterinary anthelmintics and anthelmintic drug resistance. Journal of Zankoy Sulaimani - Part A 18: 191206. https://doi.org/10.17656/jzs.10463

Eguale, T., Tilahun, G., Debella, A., Feleke, A. \& Makonnen, E. (2007). Haemonchus contortus: In vitro and in vivo anthelmintic activity of aqueous and hydro-alcoholic extracts of Hedera helix. Experimental Parasitology 116: 340-345. https://doi.org/ 10.1016/j.exppara.2007.01.019

El-Sherbini, G.T. \& Osman, S.M. (2013). Anthelmintic activity of unripe Mangifera indica L. (Mango) against Strongyloides stercoralis. International Journal of Current Microbiology and Applied Sciences 2: 401-409.

Esteban-Ballesteros, M., Sanchis, J., Gutiérrez-Corbo, C., Balaña-Fouce, R., Rojo-Vázquez, F.A., González-Lanza, C. \& Martínez-Valladares, M. (2019). In vitro anthelmintic activity and safety of different plant species against the ovine gastrointestinal nematode Teladorsagia circumcincta. Research in Veterinary Science 123: 153-158. https://doi.org/ 10.1016/j.rvsc.2019.01.004

Fthenakis, G.C. \& Papadopoulos, E. (2018). Impact of parasitism in goat production. Small Ruminant Research 163: 21-23. https://doi.org/10.1016/j.smallrumres.2017. 04.001

Gárcia, C.M.B., Sprenger, L.K., Ortiz, E.B. \& Molento, M.B. (2016). First report of multiple anthelmintic resistance in nematodes of sheep in Colombia. Anais da Academia Brasileira de Ciências 88: 397-402. https://doi.org/10.1590/ 0001-3765201620140360

Gupta, A., Singh, N., Singh, H. \& Rath, S. (2019). Prevalence of gastrointestinal helminths and assessment of associated risk factors in dairy cows from Punjab Districts, India. International Journal of Livestock Research 9: 192-199. https://doi.org/10.5455/ijlr.20181022035530

Imani-Baran, A., Abdollahi, J., Akbari, H., Jafarirad, S. \& Moharramnejad, S. (2020). Anthelmintic activity of crude powder and crude aqueous extract of Trachyspermum ammi on gastrointestinal nematodes in donkey (Equus asinus): An in vivo study. Journal of Ethnopharmacology 248: 112249. https://doi.org/10.1016/j.jep.2019.112249

Ismail, K.A., Ibrahim, A.N., Ahmed, M.A. \& Hetta, M.H. (2016). Comparison between the effect of Lawsonia inermis and flubendazole on Strongyloides species using scanning electron microscopy. Journal of Parasitic Diseases 40: 415422. https://doi.org/10.1007/s12639-014-0519-2

Kelleher, A.C., Good, B., de Waal, T. \& Keane, O.M. (2020). Anthelmintic resistance among gastrointestinal nematodes of cattle on dairy calf to beef farms in Ireland. Irish Veterinary Journal 73: 12. https://doi.org/10.1186/s13620-02000167-x

Khan, A., Tak, H., Nazir, R. \& Lone, B.A. (2018). In vitro and in vivo anthelmintic activities of Iris kashmiriana Linn. Journal of the Saudi Society of Agricultural Sciences 17: 235-240. https:// doi.org/10.1016/j.jssas.2016.05.001

Kotze, A.C. \& Prichard, R.K. (2016). Anthelmintic resistance in Haemonchus contortus. Advances in Parasitology 93: 397-428. https://doi.org/10.1016/bs.apar.2016.02.012 
Lambacher, B., Frei, C.M., Schoiswohl, J., Tichy, A., Elmer, J., Frei, J. \& Krametter-Frötscher, R. (2019). Comparison of coproscopic examination and organ diagnosis in slaughtered lambs for nematodes, especially Haemonchus contortus. Small Ruminant Research 179: 79-82. https:// doi.org/10.1016/j.smallrumres.2019.08.009

Lyndal-Murphy, M., Ehrlich, W. \& Mayer, D. (2014). Anthelmintic resistance in ovine gastrointestinal nematodes in inland Southern Queensland. Australian Veterinary Journal 92: 415420. https://doi.org/10.1111/avj.12250

Maestrini, M., Tava, A., Mancini, S., Salari, F. \& Perrucci, S. (2019). In vitro anthelmintic activity of saponins derived from Medicago spp. plants against donkey gastrointestinal nematodes. Veterinary Sciences 6: 35. https://doi.org/ 10.3390/vetsci6020035

Marley, C.L., Fraser, M.D., Fychan, R., Theobald, V.J. \& Jones, R. (2005). Effect of forage legumes and anthelmintic treatment on the performance, nutritional status and nematode parasites of grazing lambs. Veterinary Parasitology 131: 267-282. https://doi.org/10.1016/j.vetpar.2005. 04.037

Mat Yusof, A. \& Md Isa, M.L. (2016). Prevalence of gastrointestinal nematodiasis and coccidiosis in goats from three selected farms in Terengganu, Malaysia. Asian Pacific Journal of Tropical Biomedicine 6: 735-739. https:// doi.org/10.1016/j.apjtb.2016.07.001

Moraes, D., Levenhagen, M.A., Costa-Cruz, J.M., da Costa Netto, A.P. \& Rodrigues, R.M. (2017). In vitro efficacy of latex and purified papain from Carica papaya against Strongyloides venezuelensis eggs and larvae. Revista do Instituto de Medicina Tropical de São Paulo 59: e7. https://doi.org/10.1590/ s1678-9946201759007

Moreno, L. \& Lanusse, C. (2017). Specific veterinary drug residues of concern in meat production. In: New aspects of meat quality, from genes to ethics, Purslow, P.P. (editor). Tandil: Woodhead Publishing, pp. 605-627. https:// doi.org/10.1016/b978-0-08-100593-4.00025-4

Niezen, J., Waghorn, G., Graham, T., Carter, J. \& Leathwick, D. (2002). The effect of diet fed to lambs on subsequent development of Trichostrongylus colubriformis larvae in vitro and on pasture. Veterinary Parasitology 105: 269-283. https:/ /doi.org/10.1016/s0304-4017(02)00025-0

Nouri, F., Nourollahi-Fard, S.R., Foroodi, H.R. \& Sharifi, H. (2014). In vitro anthelmintic effect of Tobacco (Nicotiana tabacum) extract on parasitic nematode, Marshallagia marshalli. Journal of Parasitic Diseases 40: 643-647. https:// doi.org/10.1007/s12639-014-0550-3

Nwaorgu, O.C. (1983). The development of the free-living stages of Strongyloides papillosus. Veterinary Parasitology 13: 213-223. https://doi.org/10.1016/0304-4017(83)90058-4

Oliveira Santos, F., Ponce Morais Cerqueira, A., Branco, A., José Moreira Batatinha, M. \& Borges Botura, M. (2019). Anthelmintic activity of plants against gastrointestinal nematodes of goats: A review. Parasitology 146: 1233-1246. https://doi.org/10.1017/s0031182019000672

Olmedo-Juárez, A., Rojo-Rubio, R., Zamilpa, A., Mendoza de Gives, P., Arece-García, J., López-Arellano, M.E. \& von Son de Fernex, E. (2017). In vitro larvicidal effect of a hydroalcoholic extract from Acacia cochliacantha leaf against ruminant parasitic nematodes. Veterinary Research Communications 41: 227-232. https://doi.org/10.1007/s11259017-9687-8

Piza, M.L.S.T., Féboli, A., Augusto, J.G., Anjos, L.A., Laurentiz, A.C., Royo, V.A., Alvarenga, F.Q. \& Laurentiz, R.S. (2019). In vitro ovicidal and larvicidal activity of Psidium cattleianum Sabine leaves against gastrointestinal nematodes of naturally infected sheep. Boletim de Indústria Animal 76: 18. https://doi.org/10.17523/bia.2019.v76.e1450
Ploeger, H.W. \& Everts, R.R. (2018). Alarming levels of anthelmintic resistance against gastrointestinal nematodes in sheep in the Netherlands. Veterinary Parasitology 262: 11-15. https://doi.org/10.1016/j.vetpar.2018.09.007

Premvati, B. (1963). Effect of temperature on the development of free-living adults of Strongyloides papillosus (Wedl, 1856). Parasitology 53: 483-489. https://doi.org/10.1017/s003118 2000073935

Puspitasari, A., Setiawan, B., Koesdarto, S., Kusnoto, K., Soeharsono, S. \& Hastutiek, P. (2019). The distribution of goat gastrointestinal tractus worm egg at Rambon District of Nganjuk Regency. Journal of Parasite Science 3: 59. https://doi.org/10.20473/jops.v3i2.16519

Rashid, M., Rashid, M.I., Akbar, H., Ahmad, L., Hassan, M.A., Ashraf, K., Saeed, K. \& Gharbi, M. (2018). A systematic review on modelling approaches for economic losses studies caused by parasites and their associated diseases in cattle. Parasitology 146: 129-141. https://doi. org/10.1017/s0031182018001282

Rehder, V., Mourão, L., Nunes, M., Stien, D., Bastos, L. \& Allegretti, S. (2014). In vitro anthelmintic activity of Labramia bojeri against Strongyloides venezuelensis. Planta Medica 2014: 80. https://doi.org/10.1055/s-0034-1394898

Riyong, D., Sangkhantree, C., Champakaew, D., Jitpakdi, A., Tippawangkosol, P., Junkum, A., Chaithong, U., Wannasan, A., Yasanya, T. \& Somboon, P. (2020). Nematocidal effect of Piper retrofractum Vahl on morphology and ultrastructure of Strongyloides stercoralis third-stage infective larvae. Journal of Helminthology 94: e130. https://doi.org/10.1017/ s0022149x20000048

Rupa, A.P.M. \& Portugaliza, H.P. (2016). Prevalence and risk factors associated with gastrointestinal nematode infection in goats raised in Baybay city, Leyte, Philippines. Veterinary World 9: 728-734. https://doi.org/10.14202/ vetworld.2016.728-734

Sangkhantree, C., Riyong, D., Jitpakdi, A., Tippawangkosol, P., Junkum, A., Chaithong, U., Wannasan, A., Champakaew, D., Yasanya, T. \& Pitasawat, B. (2018). In vitro anthelminthic activity of Piper retrofractum against Strongyloides stercoralis third stage infective larvae. Southeast Asian Journal of Tropical Medicine and Public Health 49: 741-754.

Sangster, N.C., Cowling, A. \& Woodgate, R.G. (2018). Ten events that defined anthelmintic resistance research. Trends in Parasitology 34: 553-563. https://doi.org/10.1016/j.pt. 2018.05.001

Sastya, S., Kumar, R.R. \& Vatsya, S. (2018). In vitro and in vivo efficacy of Eucalyptus citriodora leaf in gastrointestinal nematodes of goats. Journal of Entomology and Zoology Studies 6: 25-30.

Shiwaku, K., Chigusa, Y., Kadosaka, T. \& Kaneko, K. (1988). Factors influencing development of free-living generations of Strongyloides stercoralis. Parasitology 97: 129-138. https://doi.org/10.1017/s0031182000066804

Singh, R., Bal, M.S., Singla, L.D. \& Kaur, P. (2016). Detection of anthelmintic resistance in sheep and goat against fenbendazole by faecal egg count reduction test. Journal of Parasitic Diseases 41: 463-466. https://doi.org/10.1007/ s12639-016-0828-8

Swai, S.E. \& Wilson, R.T. (2017). Helminths and Protozoa of the gastrointestinal tract of ruminants in Tanzania. Animal Review 4: 21-34. https://doi.org/10.18488/journal.ar.2017. 42.21.34

Swargiary, A., Daimari, M. \& Roy, M.K. (2020). Survey and documentation of anthelmintic plants used in traditional medicine system of tribal communities of Udalguri district of Assam, India. Journal of Applied Pharmaceutical Science 10: 46-54. https://doi.org/10.7324/japs.2020.101006 
Tsehayneh, B. \& Melaku, A. (2019). In vitro egg hatchability inhibition effect of Albizia gummifera, Phytolacca dodecandra, and Vernonia amygdalina against natural infection of ovine GIT nematodes. Journal of Medicinal Botany 3: 5-7. https:// doi.org/10.25081/jmb.2019.v3.4249

Viney, M. (1999). Exploiting the life cycle of Strongyloides ratti. Parasitology Today 15: 231-235. https://doi.org/10.1016/ s0169-4758(99)01452-0

Viney, M.E. (1996). Developmental switching in the parasitic nematode Strongyloides ratti. Proceedings of the Royal Society of London. Series B: Biological Sciences 263: 201-208. https:// doi.org/10.1098/rspb.1996.0032
Zajac, A.M. (2011). Veterinary Clinical Parasitology. 8th edition. London: John Wiley and Sons, pp. 1-368.

Zazharska, N., Boyko, O. \& Brygadyrenko, V. (2018). Influence of diet on the productivity and characteristics of goat milk. Indian Journal of Animal Research 52: 711-717. https:// doi.org/10.18805/ijar.v0iOF.6826

Zvinorova, P.I., Halimani, T.E., Muchadeyi, F.C., Matika, O., Riggio, V. \& Dzama, K. (2016). Prevalence and risk factors of gastrointestinal parasitic infections in goats in lowinput low-output farming systems in Zimbabwe. Small Ruminant Research 143: 75-83. https://doi.org/10.1016/ j.smallrumres.2016.09.005 